\title{
ABOUT POSSIBILITY OF USAGE METHODOLOGICAL APPROACHES TO BANKRUPTCY PREDICTION
}

\author{
Ruslan Druzin \\ Taurida National V. I. Vernadsky University \\ druzinrv@gmail.com
}

\begin{abstract}
Analysis of the most common foreign methods showed that they were designed to analyze enterprises in the sustainable economic development with low-shadowing of the economy. The most appropriate retrospective analysis results were obtained using Springate model, Lis ratio and Beaver ratio. Domestic methods analysis allows us to conclude that they make it difficult to account criterion of insolvency using a number of factors. Ukrainian researchers, as well as foreigners, use indexes for bankruptcy prediction that are based on convolution values of different insolvency signs. However, we believe that usage of a single indicator as a result doesn't allow us to make an insolvency diagnosis. The reason is high probability of an erroneous calculation because of the unreliability of the data used. Also, one of domestic methods problems is their orientation to the official statistics that increases the error due to significant domestic shadowing economy.
\end{abstract}

\section{Keywords}

bankruptcy; crisis; enterprises; creditor; Ukraine

\section{JEL Classification}

C53

\section{Introduction}

Insolvency prediction on early stages is one of the main goals of financial studies of bankruptcy. This problem has principal place in the economic studies of bankruptcy. International and domestic scientists, such as Altman (1968), Beaver (1966), Andrushchak (2004), Tereshchenko (2006), Chepurko (2000) and others worked with this problem.

The aim of this work is to determine the methodological approaches of bankruptcy prediction in Ukraine. The object of research is bankruptcy prediction of enterprises in Ukraine. The subject of the study is methodological approaches for bankruptcy prediction in Ukraine.

\section{Main task}

In this work were used such research methods as analysis and synthesis, system analysis, graphical method, the method of modeling cause-and-effect relationship, the method of approximation.

\section{Results of the study}

Company's incapability to ensure compliance with the requirements of creditors for 3 months from the due date of payment is the main feature of bankruptcy. When this period is ended, creditors have the right to sue the debtor for bankruptcy.

In the international and domestic practice, the most common models for assessing the financial condition of the company and its propensity to bankruptcy is following economic models that are built on the basis of financial ratios (Altman, 1968; 
Andrushchak, 2004; Beaver, 1966; Bernstein, 1996; Chepurko, 2000; Druzin, 2009; Harutyunyan, 2002; Kizim, 2004; Tereshchenko, 2006):

- $\quad$ determination of bankruptcy probability based on Altman Z-score;

- $\quad$ Conan and M. J. Holder model;

- Lis' model;

- Taffler's Z-Score;

- $\quad$ R. Saiffulin and G. Kadykov discriminant- five-factor model;

- $\quad$ Universal (general-purpose) model based on the discriminant function;

- $\quad$ Chepurko's V.V. measure for the degree of financial stability;

- Beaver's ratio;

- $\quad$ The bankruptcy prediction based on the Springate score;

- $\quad$ Model for bankruptcy diagnostic of agricultural enterprises (Sumy, Ukraine).

Let's calculate these models for bankrupt firms in Ukraine (sample - 15 companies from different regions with different organizational-legal forms).

To calculate bankruptcy probability of enterprises in Ukraine that were selected as the base of this study, we chose ten models. It was made to level subjectivity factor, because different models are adapted to the specific conditions, branches, periods etc. It is possible to provide an objective assessment of businesses bankruptcy probability only in the case when we would base our researches on number of models and synthesize these results to present an overall assessment of bankruptcy possibility.

Direct bankruptcy risk determination of analyzed enterprise on these models is carried out with marginal aggregate ratios.

Each model has its advantages and limitations. Let's analyze it with Table 1 which contains synthesize basic parameters of different models of bankruptcy probability determination.

We are going to calculate basic indicators for the three years before the crisis for enterprises that were chosen as a base of research to determine the selected methods degree of applicability (validity).

To interpret the obtained results in terms of bankruptcy risk we'll assign the corresponding index value of 1 if the method predicts bankruptcy, in other case assign 0 . For a number of techniques intermediate values are possible $(0.25,0.5)$.

Based on the table, we can make the following conclusions.

Enterprises, which showed extreme values on set parameters (maximum reliability of bankruptcy prediction - JSC «Predgor'e», minimum reliability - JSC «Primor'e», JSC «Named Chkalova»), that predict bankruptcy, do not show reality of prediction and illustrate some facts. For the maximum values it confirms protracted crisis in a company, whichbegan more than three years before bankruptcy initiation, for the minimum value confirms coming to bankruptcy.

Table 1 Bankruptcy prediction model

\begin{tabular}{|l|l|}
\hline \multicolumn{1}{|c|}{ Type } & \multicolumn{1}{c|}{ Resume } \\
\hline Altman Z-score & $\begin{array}{l}\text { As Ukrainian enterprises operating in different } \\
\text { circumstances, we cannot mechanically use this data } \\
\text { model. }\end{array}$ \\
\hline Conan and M. J. Holder model & $\begin{array}{l}\text { All considered foreign models have several drawbacks } \\
\text { when used in Ukraine: on the performance of Ukrainian } \\
\text { enterprises strongly affected by non-economic factors, } \\
\text { many indicators do not have the same influence on the } \\
\text { financial stability of enterprises in Ukraine, as they have } \\
\text { in the developed world, and vice versa, the proposed } \\
\text { boundaries of stability often unattainable for domestic } \\
\text { enterprises. }\end{array}$ \\
\hline Taffler's Z-Score & \begin{tabular}{l} 
The model is applicable to national enterprises. \\
\hline $\begin{array}{l}\text { R. Saiffulin and G. Kadykov discriminant- } \\
\text { five-factor mode }\end{array}$
\end{tabular} \\
\hline
\end{tabular}




\begin{tabular}{|l|l|}
\hline $\begin{array}{l}\text { Universal (general-purpose) model based on } \\
\text { the discriminant function }\end{array}$ & $\begin{array}{l}\text { The model developed by Ukrainian economist. } \\
\text { Therefore, it is fully adapted for Ukrainian companies. }\end{array}$ \\
\hline $\begin{array}{l}\text { Chepurko's V.V. measure for the degree of } \\
\text { financial stability }\end{array}$ & $\begin{array}{l}\text { Analysis of Ukrainian enterprises showed that the } \\
\text { assessment of risk of bankruptcy may not coincide with } \\
\text { Be actual financial condition of the company. }\end{array}$ \\
\hline $\begin{array}{l}\text { Model for bankruptcy diagnostic of model } \\
\text { agricultural enterprises (Sumy, Ukraine) }\end{array}$ & $\begin{array}{l}\text { Reflect the actual probability of bankruptcy of } \\
\text { agricultural enterprises. }\end{array}$ \\
\hline $\begin{array}{l}\text { Source: Druzin, R. V. (2009), Methodological approaches to the prediction of insolvency in developed } \\
\text { countries, Problems of Economics and Management: International Research and Production magazine, 49- }\end{array}$
\end{tabular}
55.

We have to exclude enterprises with extreme values on the set of indicators to select the prediction techniques (JSC «Predgor'e», JSC «Primor'e», JSC «Named Chkalova»).

Next step is to sum up the degree of forecast verification with shared coefficients for the first year -0.25 , for the second year -0.5 , for the third year -1.00 .Also we have to bring the calculated indexes to the total denominator (the maximum value of the index -21) to analyze the degree of bankruptcy prediction indicators reliability. Results are represented on figure 1-2.

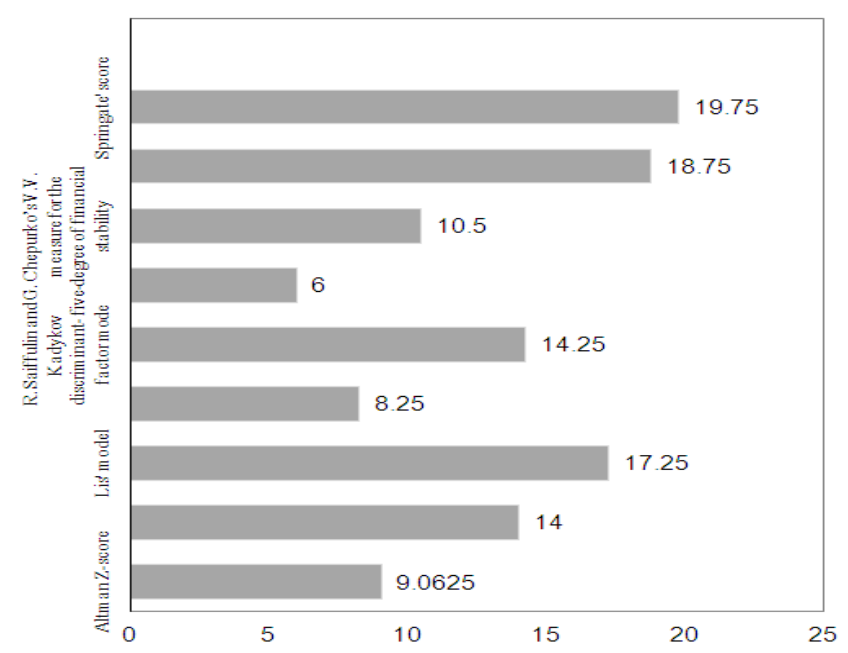

\section{Figure 1 Sum score of verification bankruptcy prediction methodological approaches of the Ukrainian enterprises \\ Source: by author}

For the analyzed methods the minimum value (agricultural enterprises bankruptcy diagnostic model-the cumulative value - 0 ) indicates inability of usage this technique for the Crimean agricultural enterprises.

Also, low values were obtained using Altman-score (9.0625), Tafler's model (8.25) and the universal discriminant function (6.0), which was built on statistics American and European companies. This is due to their focus on capitalization rates businesses and official data reporting.

The maximum value of bankruptcy procedures verification indicators (Springate model, the second-highest rank - Beaver ratio, the third - Lis ratio) allows us to select methods for bankruptcy prediction of agricultural enterprises in Ukraine. 


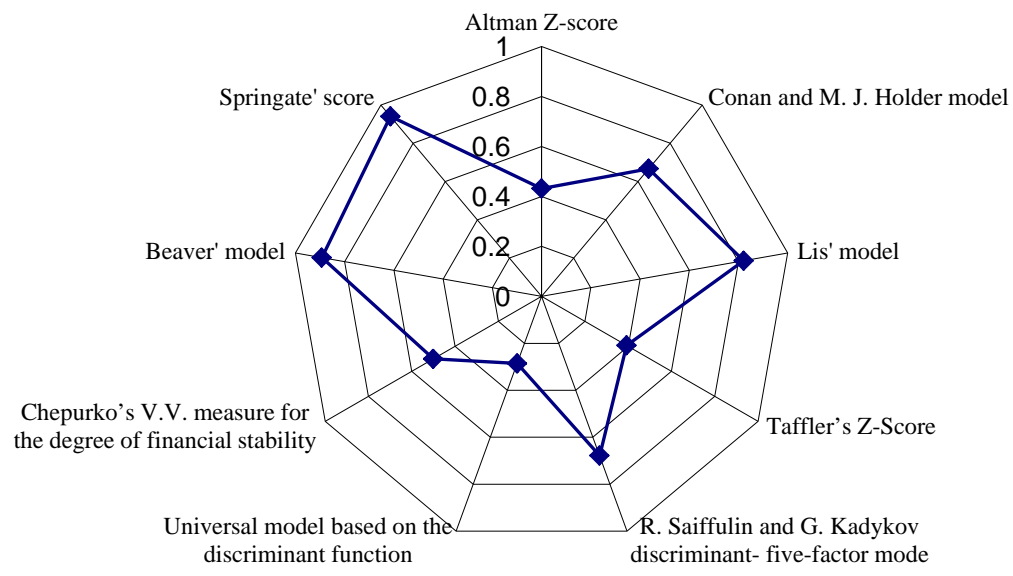

Figure 2 Degree of verification bankruptcy prediction methodological approaches of the Ukrainian enterprises

Source: by author

On the basis of this analysis JSC “Plodovid” (negative values for three years - 20082010) was justified by the need to improve the company to sanitation.

\section{Conclusions}

Analysis of the most common foreign methods showed that they are intended for use by businesses in the sustainable economic development of low-shadowing of the economy. The most appropriate based on the results of the retrospective analysis were obtained using Springate' model, Lis' factor, factor Beaver.

Analysis of the domestic procedures suggests that they use a large number of factors make it difficult calculation criteria of insolvency. Ukrainian researchers, as well as foreign ones, are used to predict performance, formed on the basis of the convolution values of different signs of insolvency. However, we believe that the use of a single indicator as a result cannot make a diagnosis of insolvency, as it is likely due to an incorrect calculation of the unreliability of the data used. Also, one of the problems of domestic procedures is their orientation to official statistics, which increases the error due to significant shadowing of the domestic economy.

\section{References}

Altman, E. I. (1968), Financial Ratios, Discriminate Analysis and the Prediction of Corporate Bankruptcy, Journal of Finance, 589-609.

Andrushchak, E. M. (2004), Diagnostic of bankruptcy of Ukrainian enterprises, Finance of Ukraine, 118-124.

Beaver, W. (1966), Financial Ratios as Predictors of Failure, Empirical Research in Accounting, Selected Studies, 71-111.

Bernstein, L. A. (1996), Financial Statement Analysis: Theory, Practice and Interpretation, Finance and Statistics.

Chepurko, V. V. (2000), Economic risk of agricultural production: theory, methodic management, Simferopol, Tavriia. 
Druzin, R. V. (2009), Methodological approaches to the prediction of insolvency in developed countries, Problems of Economics and Management: International Research and Production magazine, 49-55.

Harutyunyan, A. B. (2002) Experience with models and Fulmer Springeyta in assessing Hungarian agricultural enterprises, Audit and Financial Analysis, 200-204.

Kizim, N. A. (2004), Assessing and predicting insolvency of enterprises, Publishing House INZHEK, Kharkiv.

Tereshchenko, O. O. (2006), Financial crisis management in the enterprise, KNEU, Kiyv. 